University of Nebraska - Lincoln

DigitalCommons@University of Nebraska - Lincoln

Differential parasitism of seed-feeding Cydia (Lepidoptera: Tortricidae) by native and alien wasp species relative to elevation in subalpine Sophora (Fabaceae) forests on Mauna Kea, Hawaii

\author{
Peter T. Oboyski \\ University of Hawaii at Manoa, poboyski@nature.berkeley.edu \\ John W. Slotterback \\ University of Hawaii at Manoa \\ Paul C. Banko \\ USGS
}

Follow this and additional works at: https://digitalcommons.unl.edu/usgsstaffpub

Oboyski, Peter T.; Slotterback, John W.; and Banko, Paul C., "Differential parasitism of seed-feeding Cydia (Lepidoptera: Tortricidae) by native and alien wasp species relative to elevation in subalpine Sophora (Fabaceae) forests on Mauna Kea, Hawaii" (2004). USGS Staff -- Published Research. 634.

https://digitalcommons.unl.edu/usgsstaffpub/634

This Article is brought to you for free and open access by the US Geological Survey at DigitalCommons@University of Nebraska - Lincoln. It has been accepted for inclusion in USGS Staff -- Published Research by an authorized administrator of DigitalCommons@University of Nebraska - Lincoln. 


\title{
Differential parasitism of seed-feeding Cydia (Lepidoptera: Tortricidae) by native and alien wasp species relative to elevation in subalpine Sophora (Fabaceae) forests on Mauna Kea, Hawaii
}

\author{
Peter T. Oboyski ${ }^{1, *}$, John W. Slotterback ${ }^{1}$ and Paul C. Banko ${ }^{2}$ \\ ${ }^{1}$ Pacific Cooperative Studies Unit (University of Hawai'i atMânoa), USGS Pacific Island Ecosystems Re- \\ search Center, Kîlauea Field Station, P.O. Box 44, Hawai’i National Park, Hawai’i 96718; ${ }^{2}$ USGS Pacific \\ Island Ecosystems Research Center, Kîlauea Field Station, P.O. Box 44, Hawai'i National Park, Hawai'i \\ 96718; *Author for correspondence. Current address: Department of Environmental Science, Policy, and \\ Management, Division of Insect Biology, University of California, 201 Wellman Hall, MC3112 Berkeley, \\ California 94720, USA (e-mail: poboyski@nature.berkeley.edu; phone: (510)-642-3362; fax: (510)-642- \\ 7428)
}

Received 30 April 2004; accepted in revised form 3 June 2004

Key words: Alien species, Biological control, Elevation gradient, Moth conservation, Non-target, Parasitism

\begin{abstract}
Alien parasitic wasps, including accidental introductions and purposefully released biological control agents, have been implicated in the decline of native Hawaiian Lepidoptera. Understanding the potential impacts of alien wasps requires knowledge of ecological parameters that influence parasitism rates for species in their new environment. Sophora seed-feeding Cydia spp. (Lepidoptera: Tortricidae) were surveyed for larval parasitoids to determine how native and alien wasps are partitioned over an elevation gradient (2200-2800 m) on Hawaii Island, Hawaii. Parasitism rate of native Euderus metallicus (Eulophidae) increased with increased elevation, while parasitism rate by immigrant Calliephialtes grapholithae (Ichneumonidae) decreased. Parasitism by Pristomerus hawaiiensis (Ichneumonidae), origins uncertain, also decreased with increased elevation. Two other species, Diadegma blackburni (Ichneumonidae), origins uncertain, and Brasema cushmani (Eupelmidae), a purposefully introduced biological control agent for pepper weevil, did not vary significantly with elevation. Results are contrasted with a previous study of this system with implications for the conservation of an endangered bird species that feed on Cydia larvae. Interpretation of results is hindered by lack of knowledge of autecology of moths and wasps, origins, phylogeny, systematics, competitive ability, and physiological limitations of each wasp species. These factors should be incorporated into risk analysis for biological control introductions and invasive species programs.
\end{abstract}

\section{Introduction}

Parasitism of native Hawaiian insects by alien wasps has been of growing concern in the last few decades (Howarth 1983b; Gagne and Howarth 1985; Follet and Duan 1999; Follet et al. 2000; Asquith and Miramontes 2001; Henneman and Memmott 2001; Alyokhim and Messing 2003). 
Alien wasps have been implicated in the decline or extinction of 16 lepidopteran species in Hawaii (Gagne and Howarth 1985), with focus being drawn to wasps intentionally introduced as biological control agents (Howarth 1983b, 1991, 2000, 2001; Asquith and Miramontes 2001; Henneman and Memmott 2001). Of particular concern is the extent to which alien species can disrupt native foodwebs, either directly by depletion of particular prey species, or indirectly through competition, or apparent competition that alters predator-prey relationships (Lewis et al. 2002; Morris and Lewis 2002; Pearson and Callaway 2003). As a result, endemic prey species can become rare or extinct (Tothill et al. 1930; Gagne and Howarth 1985; Howarth 1991, 2001).

Hawaii is home to 1149 known species of Lepidoptera, 957 of which are endemic (Zimmerman 1958a, b, 1978; Nishida 2002). Although there are no Lepidoptera families or subfamilies considered endemic to Hawaii, 35 of 65 genera containing endemic species are considered endemic genera, suggesting that radiations of Hawaii species are relatively recent (Zimmerman 1948; Gagne and Howarth 1985; Nishida 2002). Some notable radiations include at least 350 species of Hyposmocoma (Cosmopterygidae) on lichens, mosses, ferns, and many genera of flowering plants; 62 species of Eudonia (Crambidae) on native plants; 49 species of Carposina (Carposinidae), mostly fruit and leaf miners; 40 species of Thyrocopa (Oecophoridae), including flightless species; 22 species of Eupithecia (Geometridae), most of which the larvae are predacious on other insects; and several species of cave-obligate Shrankia (Noctuidae) (Swezey 1954; Zimmerman 1958a, b, 1978; Montgomery 1982; Howarth 1983a; Nishida 2002).

In contrast, of 78 species of Ichneumonidae and 79 species of Braconidae (Hymenoptera), only 39 and 3 species are endemic, while 8 and 39 species are purposeful introductions, respectively (Nishida 2002). Over the 110 plus years of Hawaii's biological control program, at least 86 hymenopteran and tachinid (Diptera) parasitoid species, 12 carabid (Coleoptera) species, common mynah (Acridotheres tristis (Linnaeus)) and cane toad (Bufo marinus (Linnaeus)) have been released against lepidopteran pests (Funasaki et al. 1988). The list of accidental introductions is even greater (66 species of Ichneumonidae and Braconidae alone). Until recently, however, the extent to which these alien species have infiltrated native habitats and affected native species has not been well documented.

Recent studies demonstrate the toll that alien parasitoids exact on native Hawaiian Lepidoptera. For example, Asquith and Miramontes (2001) collected 16 species of Lepidoptera-specific parasitoids (Ichneumonidae, Braconidae: Hymenoptera) using Malaise traps in a native, montane forest on Kauai Island. Of the 2017 specimens collected, $10 \%$ ( 8 species) were Hawaiian natives, $40 \%$ (6 species) were accidental introductions, and $50 \%$ (2 species) were purposefully introduced biological control agents. Likewise, in a study of wet forest leaf-feeding Lepidoptera on Kauai Island, Henneman and Memmott (2001) found that $83 \%$ of parasitoids emerging from endemic Hawaiian caterpillars were originally introduced as biological control agents, $14 \%$ were accidental introductions, and only $3 \%$ were native to Hawaii. Similarly, $76 \%$ of wasps parasitizing seed-feeding caterpillars at high elevations on Hawaii Island are possibly of non-Hawaiian origins (Brenner et al. 2002).

There is little debate that alien species can have profound impacts on the native environments and food webs they invade. And the argument, that even well-intentioned biological control efforts can have devastating non-target impacts when proper risk analysis is not undertaken, is firmly established (Howarth 1991, 2000, 2001; Onstad and McManus 1996; Lockwood et al. 2001; Louda et al. 2003b; Carruthers 2004). It is now time to take the next step: to provide data on the ecological parameters that affect the relative impacts of both purposefully and accidentally introduced alien species in order to better evaluate risks of future control efforts and alien invasions (Arnett and Louda 2002; Louda et al. 2003a). In this study, we examine how native and alien parasitic wasps that parasitize seed-feeding Lepidoptera sort along an elevation gradient of Sophora forest in Hawaii. We hypothesize that elevation (a proxy for temperature and humidity) is an important ecological parameter for determining the relative impacts of competing parasitoid species.

Sophora chrysophylla (Salisb.) Seem (Fabaceae) is an ecologically important tree that dominates the high elevation forests of Mauna Kea on the Island of Hawaii. Sophora trees represent over 
$98 \%$ of the forest canopy from 2300 to $2800 \mathrm{~m}$ elevation (Hess et al. 1999), and provide nesting and foraging habitat for several endemic bird species (Scott et al. 1986; Hess et al. 2001). The seeds of Sophora are the primary food resource of palila, Loxioides bailleui Oustalet (Fringillidae: Drepanidinae), an endangered forest bird endemic to Mauna Kea (Van Riper 1980; Pratt et al. 1997; Banko et al. 2002). Sophora seeds are also the only known host for several species of endemic Hawaiian Cydia (Lepidoptera: Tortricidae) caterpillars (Zimmerman 1978). Furthermore, Cydia larvae found in Sophora seeds are the most important insect prey for developing palila nestlings (Banko et al. 2002), being present in $98 \%$ of fecal samples examined (USGS unpublished data).

Several species of wasps are historically known to parasitize Hawaiian Cydia larvae: the endemic Eupelmus pelodes Perkins (Eupelmidae); accidental alien Trathala flavoorbitalis (Cameron) (Ichneumonidae); and Pristomerus hawaiiensis Perkins (Ichneumonidae), origin uncertain (Perkins 1913; Swezey 1954; Zimmerman 1978). In addition to $P$. hawaiiensis, Brenner et al. (2002) reared the alien Calliephialtes grapholithae (Cresson) (Ichneumonidae); the native Euderus metallicus (Ashmead) (Eulophidae); Diadegma blackburni (Cameron) (Ichneumonidae), origin uncertain; and three specimens of the purposely introduced wasp $\mathrm{Bra}$ sema cushmani (Crawford) (Eupelmidae) from Sophora seeds containing Cydia larvae.

In their 1996-1997 study, Brenner et al. (2002) found that parasitism of Cydia caterpillars ranged from 20 to $94 \%$ with overall parasitism rate decreasing with increased elevation. Because endangered palila feed on Cydia, a finer degree of resolution was needed to evaluate the threat posed by parasitioids. In this study we expand on the results of Brenner et al. (2002) to better understand the relationship between parasitism by different wasp species and elevation.

\section{Methods}

\section{Site description}

Sample sites were located from 2200 to $2800 \mathrm{~m}$ within the Sophora dominated forests of Mauna Kea volcano, Hawaii Island, Hawaii (Figure 1). Rainfall averages $511 \mathrm{~mm} /$ year at $2260 \mathrm{~m}$ eleva- tion on the western slope of Mauna Kea (58 year average) (Juvik et al. 1993). Annual average temperature at $2600 \mathrm{~m}$ is $11^{\circ} \mathrm{C}$ with mean daily maximum ranging from 15 to $17^{\circ} \mathrm{C}$ and mean daily minimum ranging from 4 to $9{ }^{\circ} \mathrm{C}$ (Juvik et al. 1993). During the current study, rainfall and temperature varied throughout the study area with the general trend of temperature decreasing with increased elevation, and rainfall following a gradient decreasing from east to west (USGS unpublished data). Vegetation at the highest elevations is dominated by sparse Sophora chrysophylla trees. Several species of grasses (Poaceae), particularly Dactylis glomerata Linnaeus, Trisetum glomeratum (Kunth) Trin., Poa spp., and Bromus spp. become abundant along the mid-elevation sites. At the lowest elevations Sophora is codominant with Myoporum sandwicense Gray (Myoporaceae) among scattered patches of Chamaesyce olowaluana (Sherff) Croizat \& Degener (Euphorbiaceae), Coprosma montana Hillebrand (Rubiaceae), Dodonaea viscosa Jacquin (Sapindaceae), Dubautia spp. (Asteraceae), and Santalum paniculatum Hooker \& Arnott (Santalaceae) (Hess et al. 1999, USGS unpublished data).

\section{Sampling}

Sampling took place from December 1998 to December 2001 in March, June, September, and December along transects that follow an elevation gradient from tree line (circa $2900 \mathrm{~m}$ ) to $2100 \mathrm{~m}$ that were established on Mauna Kea in 1983 to monitor forest bird populations. Four transects spaced at least $500 \mathrm{~m}$ apart were chosen for each of the north, south, and west facing slopes. Sophora forest is truncated on the eastern slope of Mauna Kea by pasture lands and therefore was not included in this study. Sample stations were located at 2200, 2350, 2500, 2650, and $2800 \mathrm{~m}$ elevation (Figure 1). For four days of each sampling month, we searched for seedpods that showed signs of Cydia caterpillars $(\leq 1 \mathrm{~mm}$ silk plug) from within $50 \mathrm{~m}$ of each sample station. Trees sampled during each sampling bout were chosen by randomly selecting a distance (within $50 \mathrm{~m}$ ) and direction (at $22.5^{\circ}$ increments) from the center of each sampling station. Low Sophora tree densities at some stations, particularly at the highest and lowest elevations, meant that the same 


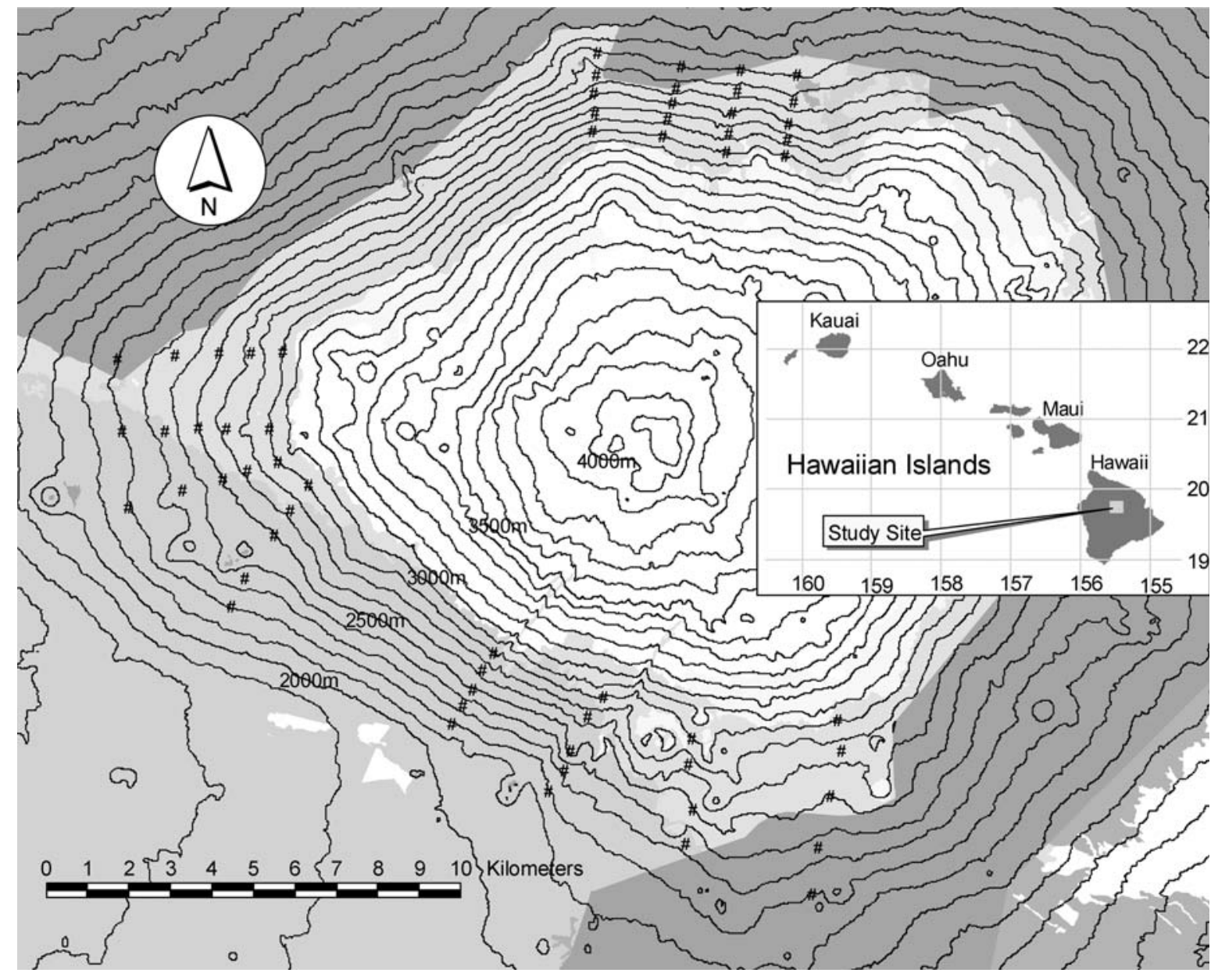

Figure 1. Location of study site on Mauna Kea volcano, Hawaii Island, Hawaii. Symbols $(\bullet)$ represent sites at which samples were collected. Contour lines are shown at $100 \mathrm{~m}$ intervals. Dark gray represents pasture lands with scattered Sophora, medium gray represents Sophora mixed with Myoporum woodland, and light gray represents Sophora dominated woodland. Elevations above woodlands and a narrow band of shrubland are barren subalpine stone desert with occasional herbs and grasses. The inset shows the study site in the context of the Hawaiian Archipelago.

trees were likely to be sampled during successive sampling bouts.

Ten seedpods collected from each of the five elevations on each of the three aspects of the mountain were returned to the laboratory for rearing of Cydia larvae (i.e. 10 pods $\times 5$ elevations $\times 3$ aspects $=150$ seedpods for each sampling bout). Following Brenner et al. (2002), each seedpod was placed individually in $240 \mathrm{ml}$ clear plastic containers fitted with screen lids (to promote air circulation and prevent molding). Containers were checked daily for the emergence of moths or wasps. After 3 months, seedpods showing no activity were dissected to determine caterpillar occupancy. Live caterpillars were returned to their seedpods to finish development. During periods when seedpod production was low, less than 10 seedpods were selected. Not all seedpods collected contained caterpillars. Therefore, sample sizes varied from site to site for each sampling bout.

\section{Analyses}

Cydia parasitism rate was calculated as the percent of wasps that emerged from all caterpillars that survived to produce either a moth or a wasp. Parasitism rate was calculated for each wasp 
species at each elevation for each month and year for a total of 63 data points. Samples were pooled across aspects for analysis of elevation, and across elevation for analyses of aspect. Analysis of seasonal trends, interactions of parameters, and variance within and among sites will be published separately. We used two-sample $t$ tests to compare the means from the three aspects. We used analysis of variance to determine if parasitism rates were significantly different for each elevation and linear regression to determine how much of the variation is explained by elevation. Although log-transformed data showed more even variances around means, there was no difference in significance of trends found in non-transformed data. Therefore, non-transformed data are presented here for greater ease of interpretation.

\section{Results}

Of 1122 caterpillars reared over a three year period (1999-2001), 443 (39.5\%) were parasitized and 679 (60.5\%) emerged as adult Cydia moths (Table 1). An additional 763 caterpillars that were collected died as a result of desiccation, pseudoparasitism (Jones et al. 1986), inadequate food within the seed they occupied, or other undetermined causes. These larvae were not included in analyses. There was no trend for overall parasitism for the three aspects (Figure 2) ( $t$ test, $p>0.10$ for all pairwise comparisons), or over the five elevations (Figure 3) $\left(R^{2}=0.01, F=0.6, p=0.46\right)$.
Of 1122 caterpillars, $16 \%$ were parasitized by Euderus metallicus (Ashmead) (Eulophidae). Eight percent were parasitized by Diadegma blackburni (Cameron), $8 \%$ by Pristomerus hawaiiensis Perkins, and $3 \%$ by Calliephialtes grapholithae (Cresson) (Ichneumonidae). Additionally, 3\% were parasitized by Brasema cushmani (Crawford) (Eupelmidae) (Table 1). Except for parasitism by $E$. metallicus being greater on the western slope than the northern slope, there were no obvious relationships between parasitoid species and aspect (Figure 2), and none were statistically significant ( $t$ test, $p>0.10)$. However, parasitism rates for some wasp species varied across elevations. Percent parasitism by $P$. hawaiiensis (Figure 4e) decreased significantly from $23 \%$ at $2200 \mathrm{~m}$ to $2 \%$ at $2800 \mathrm{~m}\left(R^{2}=0.24, F=19.6, p<0.001\right)$. Likewise, percent parasitism by $C$. grapholithae (Figure 4d) decreased significantly $\left(R^{2}=0.21\right.$, $F=16.4, p<0.001)$ with increased elevation from $8 \%$ at $2200 \mathrm{~m}$ to $1 \%$ at $2800 \mathrm{~m}$. Conversely, E. metallicus (Figure 4a) increased significantly from $5 \%$ at $2200 \mathrm{~m}$ to $24 \%$ at $2800 \mathrm{~m}\left(R^{2}=0.16\right.$, $F=11.3, p=0.001)$. The two other parasitoid species, B. cushmani and D. blackburni, (Figure 4b, c, respectively) did not vary significantly $\left(R^{2}<0.03, F<2.0, p>0.15\right)$ with elevation.

All three ichneumonid wasps are solitary endoparasitoids that emerged one per Cydia larva. Likewise, the eupelmid B. cushmani emerged one per host larva. The eulophid E. metallicus, however is a gregarious ectoparasitoid having between 1-12 parasitoids emerge from each Cydia larva. A total

Table 1. Total number of Cydia moths and parasites reared from Cydia spp. larvae inhabiting Sophora pods collected from Mauna Kea (1999-2001)

\begin{tabular}{|c|c|c|c|c|c|c|c|c|}
\hline Species: & & $\begin{array}{l}\text { Euderus } \\
\text { metallicus }\end{array}$ & $\begin{array}{l}\text { Brasema } \\
\text { cushmani }\end{array}$ & $\begin{array}{l}\text { Diadegma } \\
\text { blackburni }\end{array}$ & $\begin{array}{l}\text { Calliephialtes } \\
\text { grapholithae }\end{array}$ & $\begin{array}{l}\text { Pristomerus } \\
\text { hawaiiensis }\end{array}$ & Cydia spp. & Total \\
\hline Overall & Total & 182 & 34 & 97 & 37 & 93 & 679 & 1122 \\
\hline \multirow[t]{3}{*}{ Aspect } & $\mathrm{N}$ & 50 & 10 & 24 & 17 & 36 & 247 & 384 \\
\hline & $\mathrm{S}$ & 61 & 9 & 30 & 16 & 26 & 210 & 352 \\
\hline & $\mathrm{W}$ & 71 & 15 & 43 & 4 & 31 & 222 & 386 \\
\hline \multirow[t]{5}{*}{ Elev. (m) } & 2200 & 9 & 2 & 5 & 17 & 31 & 92 & 156 \\
\hline & 2350 & 26 & 4 & 15 & 11 & 34 & 131 & 221 \\
\hline & 2500 & 46 & 11 & 34 & 8 & 19 & 157 & 275 \\
\hline & 2650 & 61 & 13 & 31 & 0 & 6 & 163 & 274 \\
\hline & 2800 & 40 & 4 & 12 & 1 & 3 & 136 & 196 \\
\hline
\end{tabular}

Numbers are summed for all sampling bouts for all three years. Numbers for aspect are pooled across elevations. Numbers for elevation are pooled across aspects. ${ }^{a}$ Numbers represent the number of Cydia larvae parasitized by E. metallicus, rather than the number of E. metallicus that emerged because more than one wasp would often emerge from one moth larva. All other wasps emerged one per moth larva. 

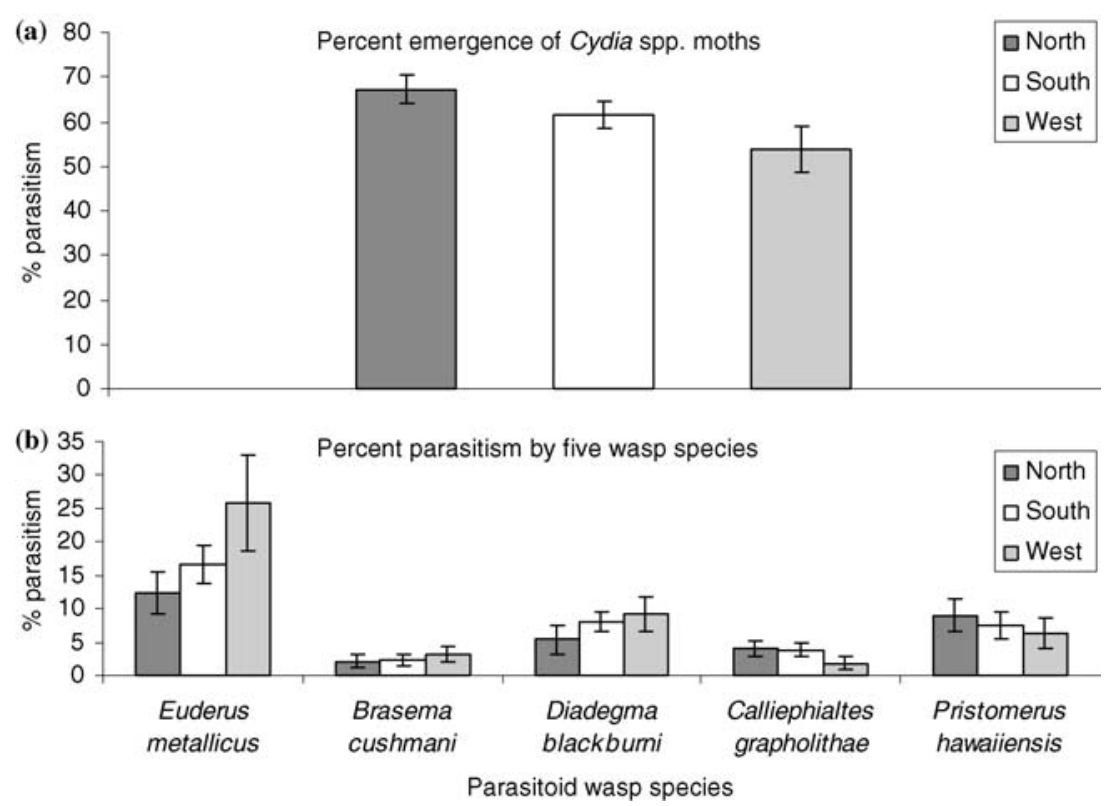

Figure 2. Mean percent emergence of Cydia moths or parasitoid wasps from Cydia larvae on Mauna Kea, Hawaii 1998-2001 relative to aspect (north, south, or west) of sample sites. (a) Mean percent emergence of $C y d i a$ moths. (b) Mean percent parasitism by five wasp species. Mean and standard error were calculated from 13 sampling bouts pooled across elevations. Note. Means for sampling bouts are different than dividing totals in Table 1 that are pooled across all sampling bouts. Pairwise $t$ tests for aspect for each wasp were not statistically significant $(p>0.10)$.

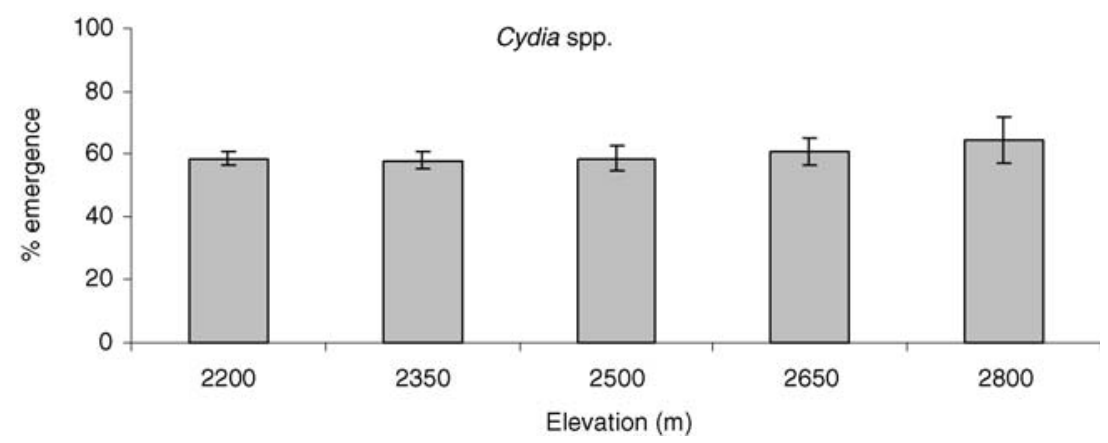

Figure 3. Mean percent emergence of Cydia moths (non-parasitized larvae) relative to elevation on Mauna Kea, Hawaii 1998-2001. Mean and standard error were calculated from 13 sampling bouts pooled across north, south, and west facing slopes for each elevation for each wasp species. Note. Means for sampling bouts are different than dividing totals in Table 1 that are pooled across all sampling bouts. There is no significant trend in emergence of Cydia over elevation $\left(R^{2}=0.01\right)$.

of 1210 individuals of E. metallicus (664 males, 546 females) emerged from 182 Cydia larvae.

\section{Discussion}

The results of this study contrast those of Brenner et al. (2002) in several important ways. Although overall parasitism rate in this study $(40 \%)$ was comparable to that of the previous $(39 \%)$, there was no trend for overall parasitism rate over elevation in the present study. The previous study demonstrated a highly significant trend for overall reduction of parasitism with increased elevation. This difference may be based partly on the areas surveyed in the two studies. The previous study 

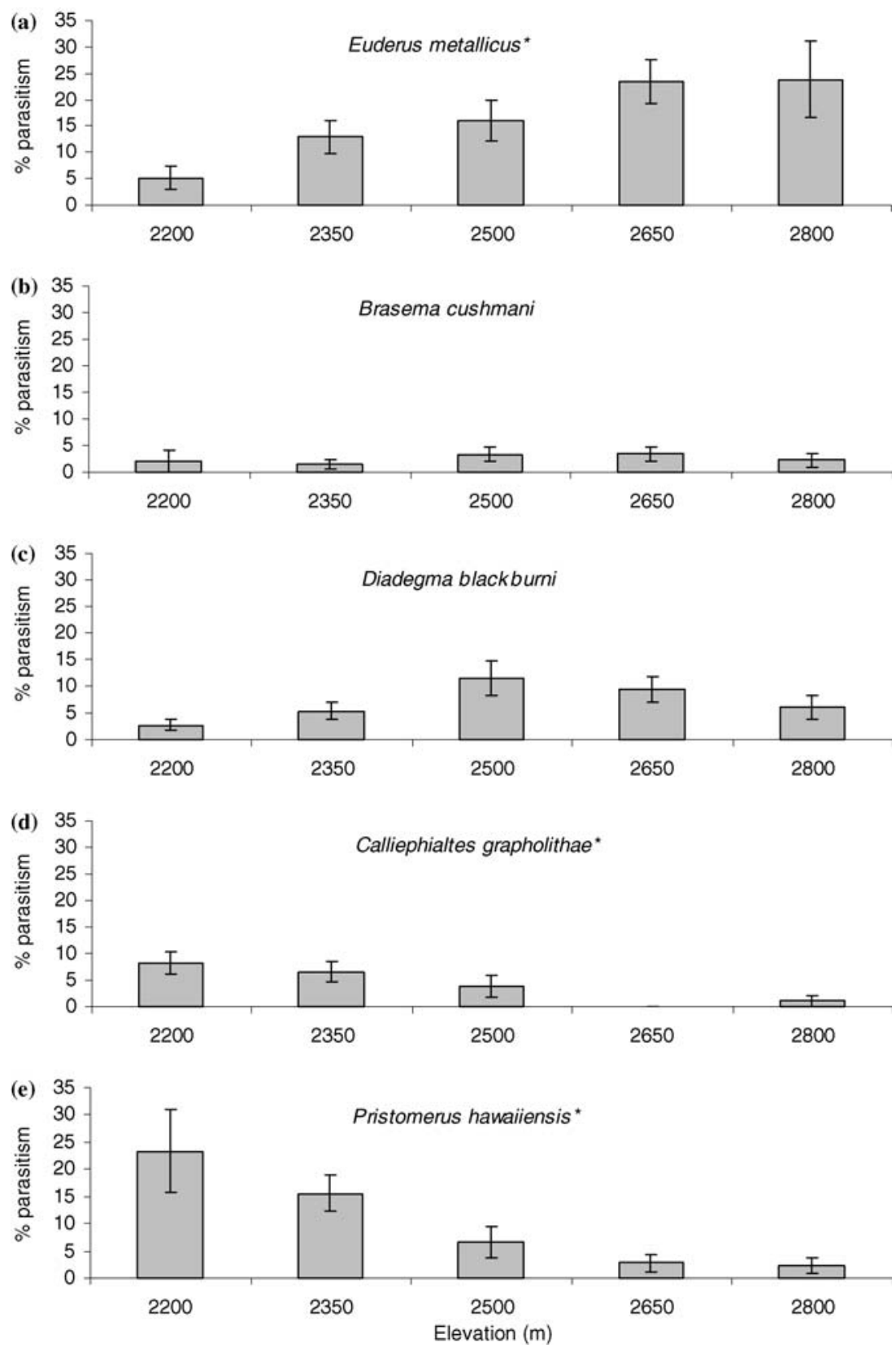

Figure 4. Mean percent parasitism of Cydia larvae by five wasp species on Mauna Kea, Hawaii 1998-2001. Mean and standard error were calculated from 13 sampling bouts pooled across north, south, and west facing slopes for each elevation for each wasp species. Note. Means for sampling bouts are different than dividing totals in Table 1 that are pooled across all sampling bouts. $(*)$ after a name indicates a statistically significant elevational trend.

included two sites below $2000 \mathrm{~m}$ where parasitism reached $100 \%$ in some months, while the present study included a greater number of sites, all above $2100 \mathrm{~m}$. One important conclusion to be drawn from the current results is that the apparent refu- gium for Cydia larvae at higher elevations in the previous study is not corroborated by this study. Banko et al. (2002) have demonstrated that the endangered forest bird, Loxioides bailleui, whose principle food resources are Sophora seeds and 
Cydia larvae, require a wide elevation gradient for adequate foraging. Lack of an upper elevation refugium, therefore, may have important consequences to the long-term viability of Cydia species as well as the birds that feed on them.

A second difference among the two studies is that in the present study parasitism by Euderus metallicus became predominant at higher elevations. The previous study indicated that parasitism by $E$. metallicus did not vary significantly with elevation. The three ichneumonid species showed similar patterns of parasitism in the two studies, with Pristomerus hawaiiensis and Calliephialtes grapholithae rates decreasing with increased elevation, although the increase in Diadegma blackburni rates at higher elevations was not significant in the present study. A third difference is the greater abundance of Brasema cushmani in the present study. Only three specimens of B. cushmani were recorded during the previous study, compared to 34 specimens ( $7 \%$ of parasitoids) recovered in the present study. This is more likely a result of more extensive and intensive sampling than a spread of this wasp in the last few years.

Given differential parasitism rates for each wasp species relative to elevation, how do the origins of each elucidate patterns of resource exploitation by native and alien species? Unfortunately, determining the origins of wasp species is problematic due to incomplete knowledge of the Hawaiian fauna, extensive commerce and travel through the Pacific region, clandestine introductions, and incomplete records of purposeful biological control introductions, particularly in the first half of the 20th century (Swezey 1931; Funasaki et al. 1988; Howarth 1991).

Of one species, Brasema cushmani (Eupelmidae), we can be sure, because it was first released in Hawaii in 1934 (Swezey 1939) to control pepper weevil (Anthonomus engenii Cano). It has since been recorded from the moth, Agonoxena argaulu Meyrick, as well as six beetle species, one tephritid fruit fly (Procecidochares utilis Stone), and the mantis Tenodora angustipennis Saussure, all alien to Hawaii (Funasaki et al. 1988). Interestingly, four of the non-target hosts (fruit fly and three weevils) are themselves purposeful introductions against invasive weeds in Hawaii (Funasaki et al. 1988). Stein (1983) indicated that although this wasp has been recorded up to $1525 \mathrm{~m}$ elevation in Hawaii, it was more prevalent below $1000 \mathrm{~m}$. He also suggests, counter-intuitively, that in Hawaii, cooler temperatures at higher elevations may shorten the egg and larval stages while prolonging pupation; which can affect its competitive status relative to other larval parasitoids. In our study, $B$. cushmani did not show any significant trends relative to elevation, but maintained a low level of parasitism across the study area (2200-2800 m).

Calliephialtes grapholithae (Ichneumonidae) was first detected in Hawaii on Oahu in 1976 (Beardsley 1980), but may have arrived accidentally much earlier. It is the most prominent parasitoid of Cryptophlebia illepida (Butler) (Tortricidae), a native pest of macadamia nut in Hawaii (Jones 2002). Previous reviews of $C$. illepida parasitoids from macadamia nuts before 1957 include Pristomerus hawaiiensis and Euderus metallicus, but not $C$. grapholithae (Namba 1957). Nor do Zimmerman (1978) or Stein (1983) mention parasitism of Lepidoptera larvae by $C$. grapholithae in their reviews of parasitoids of native Hawaii caterpillars. This wasp may therefore still be in its early stages of establishment and expansion. In this study, $C$. grapholithae was most prominent at lower elevations and declined with increased elevation.

Euderus metallicus (Eulophidae) is most likely a native to Hawaii, although Nishida (2002) lists it as possibly an accidental introduction. It was first collected in Hawaii in 1894, just 4 years after Hawaii's officially sanctioned biological control program began (Ashmead 1901; Funasaki et al. 1988). This wasp is also known from Guam, Palau, Yap, and the Caroline Atolls (Yoshimoto 1965; Yoshimoto and Ishii 1965) and is probably widespread on Pacific islands. In Hawaii it has been recorded from over 25 species of caterpillars in eight microlepidoptera families, as well as an $A g$ romyza species (Diptera: Agromyzidae) and Heteramphus swezeyi Perkins (Coleoptera: Curculionidae) (Yoshimoto 1965; Zimmerman 1978). There may be some confusion about this insect, however, because although Swezey (1915) indicates that this species feeds singly on host larvae, we reared up to 12 individuals from a single host larva. Swezey (1915) also claims to have reared a number of close relatives of this species, which are not recognized in a more recent review of Hawaiian Eulophidae (Yoshimoto 1965). In the present study, this wasp showed increased prevalence with increased elevation, indicating it is adapted to the highest elevations of Sophora forest on Hawaii. 
Diadegma blackburni and Pristomerus hawaiiensis (Ichneumonidae) are more problematic. Although first collected in Hawaii in 1883 (Ashmead 1901), D. blackburni, listed by Nishida (2002) as an accidental introduction, was also recorded from Oregon in 1897 (Carlson 1979). In the 103 years since its original description based on specimens from Hawaii, D. blackburni has gone through several name changes and may not represent the same species that was found in Oregon (Ashmead 1901; Zimmerman 1978; Carlson 1979). It may be that $D$. blackburni in Hawaii is an endemic species. Until a revision of this genus is completed, however, the place of origin cannot be assumed. In our study, D. blackburni did not vary significantly with elevation, although there was a notable increase in parasitism by this wasp from 2500 to $2650 \mathrm{~m}$.

Pristomerus hawaiiensis was first described from Hawaii in 1910 (Perkins 1910). Although the only record of this wasp outside of Hawaii is a purposeful introduction from Hawaii to California for control of pink bollworm (Pectinophora gossypiella: Gelechiidae) (Legner 1979), Fullaway and Krauss (1945) and Stein (1983) suggest it is an oriental immigrant without providing the reasoning behind their assumption. In contrast, Nishida (2002) lists this species as possibly endemic to Hawaii. Both P. hawaiiensis and D. blackburni are common and have a broad host range in Hawaii (over 25 species in seven families for $P$. hawaiiensis, and over 10 species in six families for $D$. blackburni (Zimmerman 1978)), particularly in concealed-feeding Lepidoptera (i.e. inside fruits, seeds, or twigs). This can be interpreted as a long history of adaptation in the Hawaiian Islands in the absence of competitors, or as a recent introduction of a weedy species. Zimmerman (1978) also suggests that $P$. hawaiiensis may have been confused with one or more other species for some parasitism records. Therefore we cannot definitely denote $P$. hawaiiensis as native or alien. In the current study, $P$. hawaiiensis decreased with increased elevation.

Differential parasitism of these five wasps over a $600 \mathrm{~m}$ elevation gradient suggests partitioning of the environment. The decrease in parasitism rate by $C$. grapholithae, a known alien, and increase by $E$. metallicus, presumed native, with increased elevation suggests competition between natives and aliens is forcing native wasps upslope. However, E. metallicus is a prominent parasitoid of Lepidoptera in many native forests in Hawaii and can be found at elevations below $900 \mathrm{~m}$ (Swezey 1954; Zimmerman 1978; Oboyski, unpublished data). Therefore, controlled competition experiments will be a more direct method to determine the importance of competition in this system.

Alternatively, decrease of parasitism rates with increased elevation may be an indication of physiological limitations. Cold tolerance experiments of C. grapholithae parasitizing Cydia caryana (Fitch) demonstrated that 6 week exposure to $4{ }^{\circ} \mathrm{C}$ resulted in $50 \%$ reduction in emergence of parasitoids (Yonce et al. 1996). In the present study elevation correlates with mean temperature, temperature variance, and relative humidity, with a winter average daily minimum of approximately $4{ }^{\circ} \mathrm{C}$ at $2600 \mathrm{~m}$ (Juvik et al. 1993). Decreased parasitism rates by $C$. grapholithae may reflect physiological limitations at higher elevations in our study area. Therefore, controlled experiments manipulating temperature and humidity will be important to understand how physiological limitations impact the distribution and competitive status of native and alien species.

The lack of knowledge of species identities and their places of origin may be the greatest impediment to addressing concerns of conservation in this system. Whether the current assemblage of interacting species represents millions of years of coevolution or a recent perturbation to the system will make a difference in the expected outcome of current dynamics. Swezey (1954) witnessed the decline of Omiodes (Pyralidae) caterpillars on wild banana, a result of parasitism by Trathala flavororbitalis (Cameron) and Casinaria infesta (Cresson) (Ichneumonidae) within a 30 year period following their documented arrival in Hawaii in 1910 and 1921, respectively. Likewise, Illingworth (1916) observed the extinction of a local population of Omiodes blackburni (Butler) in Palolo Valley, Oahu, via predation of their eggs and larvae by the immigrant ant Pheidole megacephala (Fabricius). Such direct, although anecdotal, observations of decline in native species are rare, or at least not well documented, but are especially instructive regarding the impacts of alien species. For three species in the current study (D. blackburni, P. hawaiiensis, and E. metallicus) it is unclear how long they have been associated with native Hawaiian Lepidoptera. Only extensive 
long-term surveys can help predict the fate of these interactions until phylogenetic and biogeographic histories of these species are completed.

Although differential parasitism rates by five wasp species in this study indicate some sorting along an elevation gradient, interpretation of results is hindered by a lack of knowledge of place of origin, identity, competitive abilities, and physiological limitations for each species. Increased biotic surveys in lesser understood biotic regions around the world will provide more certainty to biogeographic patterns of invasive species. Phylogenetic studies of proposed biological control agents can provide more certainty to the identity of species and insights into the evolutionary and physiological tendencies of control agents. Finally, it will be impossible to predict the potential impacts of incipient alien species or biological control introductions without first conducting the proper experiments to determine competitive abilities within guilds and physiological tolerances and limitations of competing species.

\section{Acknowledgements}

We thank Bernarr Kumashiro (Hawaii Department of Agriculture) for help in identifying parasitoid species. Greg Brenner, Matt Kweskin, Luanne Johnson, Steve Dougill, and Dan Goltz (all formerly with USGS Pacific Cooperative Studies Unit) provided useful comments on study design and assisted with fieldwork. Many USGS Interns were invaluable in collecting, rearing, and curating specimens. Comments from Robert Peck, David Pollock (USGS PCSU), Frank Howarth (Bishop Museum) and an anonymous reviewer greatly improved this manuscript. Access to field sites was granted by the Hawaii Department of Land and Natural Resources - Division of Forestry and Wildlife, and the US Army Garrison, Hawaii. Funding for this project was provided in part by the US Army Garrison, Hawaii, and the US Geological Survey Invasive Species Program and Wildlife and Terrestrial Resources Program. Any use of trade, product, or firm names in this publication is for descriptive purposes only and does not imply endorsement by the US Government. The opinions expressed in this product are those of the authors and do not necessarily represent the opinions of the US Government.

\section{References}

Alyokhin A.V. and Messing R.H. 2003. Parasitism of Hawaiian non-frugivorous fruit flies (Diptera: Tephritidae) by an exotic parasitoid, Eurytoma tephritidis Fullaway (Hymenoptera: Eurytomidae). Proc. Hawaii. Entomol. Soc. 36: 29-38.

Arnett A.E. and Louda S.M. 2002. Re-test of Rhinocyllus conicus host specificity, and the prediction of ecological risk in biological control. Biol. Conserv. 106: 251-257.

Ashmead W.H. 1901. Hymenoptera Parasitica. In: Sharp D. (ed.), Fauna Hawaiiensis. Cambridge University Press, Cambridge, England, pp. 277-364.

Asquith A. and Miramontes E. 2001. Alien parasitoids in native forests: the ichneumonoid wasp community in a Hawaiian rainforest. In: Lockwood J.A., Howarth F.G. and Purcell M.F. (eds), Balancing Nature: Assessing the Impact of Importing Non-native Biological Control Agents (an International Perspective). Entomological Society of America, Lanham, Maryland, pp. 54-69.

Banko P.C., Oboyski P.T., Slotterback J.W., Dougill S.J., Goltz D.M., Johnson L., Laut M.E. and Murray T.C. 2002. Availability of food resources, distribution of invasive species, and conservation of a Hawaiian bird along a gradient of elevation. J. Biogeogr. 29(5-6): 789-808.

Beardsley J.W. 1980. Notes and Exhibitions: Calliephialtes grapholithae (Cresson). Proc. Hawaii. Entomol. Soc. 23(2): 179.

Brenner G.J., Oboyski P.T. and Banko P.C. 2002. Parasitism of Cydia spp. (Lepidoptera: Tortricidae) on Sophora chrysophylla (Fabaceae) along an elevation gradient of dry subalpine forest on Mauna Kea, Hawaii. Pan-Pacific Entomol. 78(2): 101-109.

Carlson R.W. 1979. Family Ichneumonidae. In: Krombein K.V., Hurd P.D., Smith D.R. and Burks B.D. (eds), Catalog of Hymenoptera in America North of Mexico. Smithsonian Institute Press, Washington, DC, pp. 315-740.

Carruthers R.I. 2004. Biological control of invasive species, a personal perspective. Conserv. Biol. 18(1): 54-57.

Follet P.A. and Duan J. (eds) 1999. Nontarget Effects of Biological Control. Kluwer, Boston, 316 pp.

Follett P.A., Duan J., Messing R.H. and Jones V.P. 2000. Parasitoid drift after biological control introductions: reexamining Pandora's Box. Am. Entomol. 46(2): 82-94

Fullaway D.T. and Krauss N.L.H. 1945. Common Insects of Hawaii. Tongg Publishing Company, Honolulu, 228 pp.

Funasaki G.Y., Lai P.Y., Nakahara L.M., Beardsley J.W. and Ota A.K. 1988. A review of biological control introductions in Hawaii: 1890 to 1985. Proc. Hawaii. Entomol. Soc. 28: $105-160$.

Gagne W.C. and Howarth F.G. 1985. Conservation status of endemic Hawaiian Lepidoptera. Proceedings of the 3rd Congress European Lepidopterology 1982, Cambridge, pp. 74-84.

Henneman M.L. and Memmott J. 2001. Infiltration of a Hawaiian community by introduced biological control agents. Science 293: 1314-1316. 
Hess S.C., Banko P.C., Brenner G.J. and Jacobi J.D. 1999. Factors related to the recovery of subalpine woodland on Mauna Kea, Hawaii. Biotropica 31(2): 212-219.

Hess S.C., Banko P.C., Reynolds M.H., Brenner G.J., Laniawe L.P. and Jacobi J.D. 2001. Drepanidine movements in relation to food availability in subalpine woodland on Mauna Kea, Hawaii. Stud. Avian Biol. 22: 154-163.

Howarth F.G. 1983a. Ecology of cave arthropods. Annu. Rev. Entomol. 28: 365-389.

Howarth F.G. 1983b. Classical biocontrol: panacea or Pandora's box. Proc. Hawaii. Entomol. Soc. 24: 239-244.

Howarth F.G. 1991. Environmental impacts of classical biological control. Annu. Rev. Entomol. 36: 485-509.

Howarth F.G. 2000. Non-target effects of biological control agents. In: Gurr G.M. and Wratten S.D. (eds), Measures of Success in Biological Control. Kluwer Academic Publishers, Dordrecht, pp. 369-403.

Howarth F.G. 2001. Environmental issues concerning the importation of non-indigenous biological control agents. In: Lockwood J.A., Howarth F.G. and Purcell M.F. (eds), Balancing Nature: Assessing the Impact of Importing Non-native Biological Control Agents (An International Perspective). Entomological Society of America, Lanham, Maryland, pp. 70-99.

Illingworth J.F. 1916. Notes and exhibitions. Proc. Hawaii. Entomol. Soc. 3(3): 142-143.

Jones D., Jones G., Rudnicka M., Click A., Reck-Malleczewen V. and Iwaya M. 1986. Pseudoparasitism of host Trichoplusia $n i$ by Chelonus spp. as a new model for parasite regulation of host physiology. J. Insect Physiol. 32: 315-328.

Jones V.P. 2002. Macadamia integrated pest management: IPM of insects and mites attacking macadamia nuts in Hawaii. College of Tropical Agriculture and Human Resources, University of Hawaii, Manoa, 98 p.

Juvik J.O., Nullet D., Banko P.C. and Hughes K. 1993. Forest climatology near the tree line in Hawaii. Agri. Forest Meteorol. 66: 159-172.

Legner E.F. 1979. Emergence patterns and dispersal in Chelonus spp. near curvimaculatus and Pristomerus hawaiiensis, parasitic on Pectinophora gossypiella. Ann. Entomol. Soc. Am. 72(5): 681-686.

Lewis O.T., Memmott J., LaSalle J., Lyal C.H.C., Whitefoords C. and Godfray H.C.J. 2002. Structure of a diverse tropical forest insect-parasitoid community. J. Anim. Ecol. 71: 855873 .

Lockwood J.A., Howarth F.G. and Purcell M.F. (eds) 2001. Balancing Nature: Assessing the Impact of Importing Nonnative Biological Control Agents (An International Perspective). Entomological Society of America, Lanham, Maryland, $130 \mathrm{pp}$.

Louda S.M., Pemberton C.E., Johnson M.T. and Follet P.A. 2003a. Nontarget effects - the Achilles' Heel of biological control? Retrospective analyses to reduce risk associated with biological introductions. Annu. Rev. Entomol. 48: 365-396.

Louda S.M., Arnett A.E., Rand T.A. and Russell F.L. 2003b. Invasiveness of some biological control insects and adequacy of their ecological risk assessment and regulation. Conserv. Biol. 17(1): 73-82.

Montgomery S.L. 1982. Biogeography of the moth genus Eupithecia in Oceania and the evolution of ambush predation in Hawaiian caterpillars (Lepidoptera: Geometridae). Entomol. General. 8(1): 27-34.

Morris R.J. and Lewis O.T. 2002. The role of indirect interactions in structuring tropical insect communities. Oikos 97(2): 308-311.

Namba R. 1957. Cryptophlebia illepida (Butler) (Lepidoptera: Eucosmidae) and other insect pests of the macadamia nut in Hawaii. Proc. Hawaii. Entomol. Soc. 16(2): 284-297.

Nishida G.M. 2002. Hawaiian Terrestrial Arthropod Checklist, 4th ed. Technical Report No. 22. B.P. Bishop Museum, Honolulu, Hawaii, 263 pp.

Onstad D.W. and McManus M.L. 1996. Risks of host range expansion by parasites of insects. BioScience 46(6): 430-435.

Pearson D.E. and Callaway R.M. 2003. Indirect effects of hostspecific biologial control agents. Trends Ecol. Evol. 18(9): 456-461.

Perkins R.C.L. 1910. Hymenoptera (supplement). In: Sharp D. (ed.), Fauna Hawaiiensis. Cambridge University Press, Cambridge, England, pp. 600-686.

Perkins R.C.L. 1913. Introduction. In: Sharp D. (ed.), Fauna Hawaiiensis. Cambridge University Press, Cambridge, England, pp. xv-ccxxviii.

Pratt T.K., Banko P.C., Fancy S.G., Lindsey G.D. and Jacobi J.D. 1997. Status and management of the palila, an endangered Hawaiian honeycreeper, 1987-1996. Pacific Conserv. Biol. 3: 330-340

Scott J.M., Mountainspring S., Ramsey F.L. and Kepler C.B. 1986. Forest bird communities of the Hawaiian Islands: their dynamics, ecology, and conservation. Stud. Avian Biol. 9: 1431.

Stein J.D. 1983. The biology, host range, parasites, and hyperparasites of koa seed insects in Hawaii: a review. Proc. Hawaii. Entomol. Soc. 24(2/3): 317-326.

Swezey O.H. 1915. A preliminary list of the hymenopterous parasites of Lepidoptera in Hawaii. Proc. Hawaii. Entomol. Soc. 3(2): 99-109.

Swezey O.H. 1931. Records of introduction of beneficial insects into the Hawaiian Islands. In: Williams F.X. (ed.), Handbook of Insects and Other Invertebrates of Hawaiian Sugarcane Fields. Honolulu Advertiser Publishing, Honolulu, Hawaii, pp. 368-389.

Swezey O.H. 1939. Recent records of the introduction of beneficial insects into the Hawaiian Islands. Proc. Hawaii. Entomol. Soc. 10: 349-352.

Swezey O.H. 1954. Forest Entomology in Hawaii. Honolulu Star-Bulletin (B.P. Bishop Museum Special Publication 44), Honolulu, Hawaii, 266 pp.

Tothill J.D., Taylor T.H.C. and Paine R.W. 1930. The Coconut Moth in Fiji (A History of its Control by Means of Parasites). Imperial Institute of Entomology, London, England, 269 pp.

Van Riper C. 1980. Observations on the breeding the palila (Psittirostra bailleui) of Hawaii. Ibis 122: 462-475.

Yonce C.E., Tedders W.L. and Wood B.W. 1996. Cold tolerance of hickory shuckworm (Lepidoptera: Tortricidae) larvae and associated parasites. J. Entomol. Sci. 31(1): 13-19.

Yoshimoto C.M. 1965. Synopsis of the Hawaiian Eulophidae including Aphelininae (Hym.: Chalcidoidea). Pacific Insects 7(4): 665-699.

Yoshimoto C.M. and Ishii L.M. 1965. Chalcidoidea. Insects Micronesia 19(4): 138-141. 
Zimmerman E.C. 1948. Insects of Hawaii, Vol. 1: Introduction. University of Hawaii Press, Honolulu, Hawaii, 206 pp.

Zimmerman E.C. 1958a. Insects of Hawai, Vol. 7: Macrolepidoptera. University of Hawaii Press, Honolulu, Hawaii, 542 pp.
Zimmerman E.C. 1958b. Insects of Hawaii, Vol. 8: Pyraloidea. University of Hawaii Press, Honolulu, Hawaii, 456 pp.

Zimmerman E.C. 1978. Insects of Hawaii, Vol. 9: Microlepidoptera. University of Hawaii Press, Honolulu, Hawaii, 1903 pp. 